\title{
The Persistence of Political Power: A Communist 'Party Village' in Kerala and the Paradox of Egalitarian Hierarchies
}

\author{
Nitasha Kaul ${ }^{1} \cdot$ Nisar Kannangara $^{2}$
}

Accepted: 30 July 2021

(c) The Author(s) 2021

\begin{abstract}
This article combines political analysis with ethnographic fieldwork to theorise Communist party's construction of political allegiance and their persistence of power in the democratic context at a local village level in the state of Kerala in India. We provide an inaugural scholarly conceptualisation of an empirical phenomenon, known in Kerala popular parlance as 'party gramam' or the 'party village', as the focus of analysis. As we explain, a 'party village' is an administrative unit where a particular political party dominates not simply electorally but in all lived experience. We posit that the concept of 'party village' is of specific value in our understanding of various forms of current (Communist) politics. The original ascendancy of communism in the village (as in many regions of Kerala) during the twentieth century was due to its progressive ideological challenge to feudal structures of class and caste oppression. However, in democratic post-independence India, the overwhelming dominance of Communist Party in the 'party village' presents the paradox of a party with an egalitarian ideology having adapted to a persistent Hindu caste hierarchy. After situating our work within the conceptual problematisations of political party competition, and in conversation with wider communist studies literature, we provide a background to the politics of Kerala and explain the unique phenomenon of 'party villages' in Kerala. We then provide an insight into the social and economic structures of one such village, explaining the salience of these structures in relation to political allegiances. Next, we illustrate the paradox of continued caste hierarchies in a Communist Party village, and the multiple ways in which Hindu religion and caste structures are important to performing individual identity in social settings. We dissect the various means through which the grassroots Communist Party apparatus in the village maintains its dominance by adapting itself to regressive caste hierarchies for political profit at the same time as laying claim to having challenged them. In our concluding section, we place our village observations in the longer frame of historical north Kerala village politics, noting the changes over time and offering theoretical perspectives upon them. In this sense, through a mix of empirical observation with historical context and theorisation, we highlight the importance and the implications of unconventional democratic dynamics more generally.
\end{abstract}

Extended author information available on the last page of the article 
Keywords Kerala $\cdot$ India $\cdot$ Political Loyalty $\cdot$ Communist Party $\cdot$ Party Village Ethnography $\cdot$ Democracy

\section{Introduction}

This article combines political analysis with ethnographic fieldwork to provide an account - of political allegiance and the persistence of power - that is both descriptive and interpretive, addressing 'what people do as well as why they do it' (Herzog \& Zacka, 2019: 764). Through an ethnography of a village in North Kerala called Che Puram, ${ }^{1}$ we investigate the ways in which the sustained and uninterrupted political and electoral dominance of Communist Party in this 'party village' has coexisted with Hindu caste hierarchical structures over time. The original ascendancy of communist ideology (with its anti-feudal, anti-caste, anti-imperialist ethos) in the region that was to become the state of Kerala in 1956 (after Indian independence in 1947) was followed by the unique distinction of the state being a rare one anywhere in the world to elect Communists to power in 1957 on the ballot in a democratic system. The complex party-political manoeuvrings of the successive decades have been the focus of much work, but this present article is the first scholarly conceptualisation of an empirical phenomenon - known in popular parlance as 'party gramam' — of the 'party village' as the focus of ethnographic and political analysis. In the Indian context, 'party village' are referred to in the media solely via the framing of incidents of political violence or aggregate electoral data. As we explain later, such gramams are only found in the Kannur district of north Kerala, and they are much more than standard political strongholds, in terms of how the Communist Party features in people's lived experience. We posit that the concept of 'party village' is of specific value in our understanding of various forms of current (Communist) politics.

We explore the social mechanisms through which the Communist Party maintains its power in contradictory (caste) settings in relation to both religion and nationalism. Hence, this article is also a site for understanding how progressive political ideologies can adapt to regressive structures for sustained political profit. We submit that multiple, diverse and, at times, opposing practices must be taken in order to stay revolutionary while in power in a caste society. These include both material and symbolic or ideological practices regarding, among others, the family, the economic structure and political representation. Inter alia, this also illustrates the difficulties of a revolutionary movement to remain as such, much past its coming to power and more so in the context of democratically framed politics with its electoral exigencies. In this sense, through a mix of empirical observation with historical context and careful theorisation, we highlight the importance and the implications of unconventional democratic dynamics more generally. For its primary data, the article

\footnotetext{
${ }^{1}$ Che Puram is a pseudonym. The real village is located in the northern (Kannur) region of the state of Kerala in southern India.
} 
draws upon ethnographic fieldwork carried out in the village from October 2014 to August 2016, followed by a fieldwork visit in April 2019. ${ }^{2}$

The structure of the article is as follows. In the first section, we situate our work within the conceptual problematisations of political party competition, and in conversation with wider communist studies literature. We then provide a background to the politics of Kerala and explain the unique phenomenon of what are called 'party villages' in Kerala. In the second section, we provide an insight into the social structure of the village Che Puram in terms of its caste groupings and their corresponding resources in terms of average land holdings, explaining the salience of these structures in relation to political allegiances. In the third section, we illustrate the paradox of continued caste hierarchies in a Communist Party village and the multiple ways in which Hindu religion and caste structures are important to performing individual identity in social settings, be they of festival celebrations, marriage choices or cremation decisions. In the fourth section, we dissect the various means through which the grassroots Communist Party apparatus in the village maintains its dominance by adapting itself to regressive caste hierarchies at the same time as laying claim to having challenged them. In our concluding section, we place our village observations in the longer frame of historical north Kerala village politics, noting the changes over time and offering theoretical perspectives upon them.

\section{Party Politics, Kerala Politics and 'Party Villages'}

Our study focuses on a unique phenomenon concerning the Communist party's construction of political allegiance and their persistence of power in the democratic context at a local village level in the state of Kerala in India. However, in order to appreciate the rationale for our focus, it is important to drill down from the broader literatures that link to the functioning of the communist party in a democratic context. Here, the analytical accents can vary from attention to the ways in which political party competition is connected to social divisions or cleavages to the ways in which communist political parties adapt to post-communist/democratic contexts. For instance, since the early works with a structural-functionalist ethos (Lipset \& Rokkan, 1967), much of the western literature on political party competition considers the parties to be resulting from pre-existing political cleavages which can be conceived of as 'strongly structured and persistent lines of salient social and ideological divisions among politically important actors' (Whitefield, 2002: 181). While it is acknowledged that these divisions involve 'passing on of identities and interests, formally via institutions or informally through families', scholars note that demonstrating these factors is frequently difficult (ibid.: 191). The general understanding tended to be that as democracies consolidate, these cleavages would decline over time as voters would be able to choose in ways that are individual and not encumbered by historical and cultural factors. This has not

\footnotetext{
2 This included participant observation of everyday political events in the village, two major elections, cultural and social events (a dozen religious festivals, marriages and death rituals associated with different castes and ethnic groups).
} 
been borne out in practice widely because the stakes in political competition have not declined (Enyedi, 2008: 288), and political parties have often not just reflected but articulated cleavages by actively naturalizing identities and collectivities by integrating them into coherent blocks (De Leon et al, 2009: 196). Survey studies of the political party in Eastern Europe and post-Communist democracies specifically find party cleavages to be important (Rohrschneider \& Whitefield, 2009). Moreover, in such contexts, the Communist successor parties also appeared to confess a 'neotraditionalism', adapting to democratic systems by accommodating with ethnic politics or populist parties (Janos, 1993; Ishiyama, 1999a).

On the whole, we might note the following. The understanding of articulations across social divisions is important work, and relatedly, doing so involves a comprehension both at individual micro attitudes and party macro strategy levels. Individual political attitudes may function in ways that there exist differences at operational and ideological levels with regard to economic or political stances, instead of being consistent and summarisable along a single dimension of ideology (see Fleishman, 1988). Political parties, including Communist or Communist successor parties, may harness public symbolism (such as through memories of prior sacrifice for collective consciousness) along with paternalism, traditional relationships or technocracy (Janos, 1993: 7-18) to create channels of interest articulation (Ishiyama, 1999b: 53). While several western scholars have studied Communist party dynamics over time, the bulk of the work is neither ethnographic nor focused on societies outside postSoviet East European states. Often, the political cleavages are sought to be measured through quantitative analysis, with a concern for the stability and volatility of electoral outcomes (in these terms, we would see that Kerala has high cleavage and low volatility, see Heath, 2005).

Beyond the broad-brush analyses that compare electoral or survey data across countries, using social cleavage theories to study party systems is not the only viable means for making sense of the heterogeneity and complexity presented by developing countries. When stylised cleavage frameworks are used with data, for instance by Chhibber and Petrocik (1988), to explain Congress party success in India at a national level, an important insight is that it is the local level that is most significant. And at this local level, caste plays a crucial role, so that 'Every party whether avowedly communal or ideologically opposed to such vertical segmentation (such as the Communists), turned to segmental cleavages such as caste to mobilize electoral support' (ibid.: 200). Lieten (1979a: 313) had referred to the fragmented nature of Indian society, noting numerous oppositional groupings (beyond the standard dichotomous cleavages of centre/periphery, church/state, land/industry and owner/worker) that carry salience (including tribal/non-tribal, Hindu/Muslim, sharecropper/landlord, landless labourer/rich peasant, employed/unemployed), plus the social stratification of the caste system that, from ten to five centuries BC onwards, has been 'codified ideologically in the varna system as a rationalisation of the relations of production prevalent at that time... [with] real structural unit of the system [being] the innumerable localised and proliferating jatis' (ibid.: 314). What is more, Kerala's history and present shows important variations in terms of religion, caste, region and democratic dynamics. It is to explicating these complications that we now turn. 
As Kurien (1994: 391) details, the three religious groupings - Hindus, Christians, Muslims - have existed in Kerala for well over a thousand years. The evolution of the caste system in Kerala also deviated from the ideal schema whereby 'the Kshatriyas [warrior caste] were rare and the Vaishyas [merchant caste] nonexistent ${ }^{3}$... The Christians and the Muslims were the main business and trading communities in Kerala'. In addition to untouchability, in Kerala 'the notion of pollution by contact was taken a step further to include "atmospheric pollution" - pollution from a distance, and, in the case of the lowest castes, even by sight' (ibid.: 392). During the period of colonial rule, the nature of national-communal forces and feudal hierarchies in regions of what was to become Kerala produced striking politicalcommunal responses to economic structures of land ownership with its correlates of caste and class (this is especially the case for north Kerala, which witnessed the Malabar Rebellion of 1921-1922; see Miller, 1976; Dale, 1980; Wood, 1987; Kurien, 1994: 405; Panikkar, 1989; Oommen, 1995) as well as social accommodations across rigid divides of caste, nationalism and communism (Mannathukkaren, 2013; Menon, 1994).

Democracy has produced complex paradoxes in Indian politics and society (Vanaik, 2007), even more so in Kerala in the post-colonial period where the communist, communal and the casteist social forces co-exist, caste and communal organisations are highly institutionalised and where 'political parties of the State condemn communalism but make use of the support of communal organisations to win elections... [so that] various secular and the non-secular factors operate simultaneously' (Nair, 1994: 260). As we mentioned at the outset, during the early cold war period, Kerala elected a communist government in democratic elections, and unlike another Indian state of West Bengal (see Bhattacharyya, 2010; Das \& Mahmood, 2015; Kerswell, 2018), Communist dominance in Kerala has not waned over time. In north Kerala, in the region of Kannur - where the village Che Puram is located - the Communist party dominance is part of the fabric of not just politics but also everyday life. Unlike the post-communist states where the Communist (or Communist-successor) parties had to find ways of strategically accommodating with the democratic domain after the transition to democracy, in Kerala, the communists have had to accommodate to the demands of a post-colonial electoral democracy from the first.

Having situated ourselves into the larger conceptual literature thus far, we want to zoom into Kerala electoral politics and the party village — in order to show why we study a village in the Kannur region of north Kerala where the Communist party dominates politics and life, and how they do so. But before refocusing to that, we want to index and emphasise two points in this paragraph. First, the empirical data has repeatedly observed the region of Kannur in north Kerala to show a particular pattern of voting behaviour, but our work is the first to provide an understanding of it in a local sense. So, for instance, Sunilraj and Heath (2017) note that Kerala has a party stability, programmatic and well-institutionalised party system. They

\footnotetext{
3 'The Nayar caste took the place of the Kshatriyas but they were regarded as Sudras by the local Brahmins. The Ezhavas came below the Nayars, followed by the slave castes' (ibid.: 392).
} 
study the survey data from 2011 to find close ties between political parties and caste-community cleavage, concluding with these words, 'These findings also indicate that there is a clear geographic structure to contemporary patterns of voting behaviour that is shaped by the historical legacy of the communist Party...In those places where the communists first established a stronghold, people still continue to support the party, irrespective of caste and class and caste identities...So what then accounts for the enduring legacy of 1957? We suggest that part of the story relates to the development of party organizations and intermediary organizations which have persisted over time' (ibid.: 201). Our work can be read as a fine-grained, ethnographically sourced and bottom-up answer to this question of what accounts for this geographical dimension of political alignments (that of a village in the Kannur region to the Communist party). Second, wider studies of communist (and communist successor) parties in post-communist democratic settings have suggested that democratic consolidation in one significant sense has meant 'the widespread acceptance of the general principle of democratic competition', and the notion of alternation of power between rivals (Ishiyama, 1999b: 54-55). What we show with the region in Kerala and specifically with the 'party village' is the reverse. Although Kerala has seen the two main political fronts (Communist-led LDF and Congressled UDF) alternate power for the last several decades, all the political parties competing in the democratic fray do not adhere to the democratic rules of the game. Procedurally, there are elections, and substantively, there is representation; however, the dynamics in the party village evidence de jure multi-party competition with free elections but little de facto competitive political expression. Our study of the village dynamics in the Althusserian frame shows how it might be the case.

Kerala was created as a linguistic state in 1956 and comprised the old princely states of Travancore, Cochin and the Malabar districts of Madras Presidency of British Raj. In the first elections after its creation, the undivided Communist Party of India (CPI) came to power in the Kerala legislative assembly with a majority of seats and $40.7 \%$ of the vote (Gough, 1967). These democratic successes for a communist government and the unusual ideological spread of Communism in an Indian state had invited large international attention in the 1950s and 1960s. The explanations ranged broadly from decline and corruption of regional Congress party to the early and specific roots of the Kerala Communists and work with landless classes to their skilled leadership or manipulation of agrarian unrest or harnessing of communal forces, thus underlining the political complexity of Kerala in terms of demographic composition, party competition and communalism (see Harrison, 1960; Pulickaparampil, 1963; Hardgrave, 1964; Gough, 1967; Fic, 1970; Turlach, 1970; Davey, 1972; Lieten, 1975; Nossiter, 1982; Oommen, 1992; Mannathukkaren, 2016). This first Communist government was short lived as the central government in New Delhi removed it in 1959, but the reforms they carried out between 1957 and 1959 (see Lieten, 1977, 1979b) paved the way for significant changes to education policy, political economy, land, policing and administration. The elections in 1960 brought a coalition government - Indian National Congress (INC) and People's Socialist Party, supported by the Muslim League - to power, but the turmoil between various factions in the parties continued, and the President's rule was 
again imposed from the Centre in $1964,{ }^{4}$ the year when both the INC in Kerala and the Indian Communist Party split into two: the Communists into CPI and CPI-M (Marxist faction). The elections of 1965 resulted in a win for CPI-M. The intraparty conflicts and cross-party manoeuvrings and alliances continued for several years, resulting in two main electoral contenders that are current even now five decades later - the United Democratic Front, UDF (Congress-led coalition with factions of Muslim League and several other parties) and the Left Democratic Front, LDF (CPI-M-led coalition with CPI, Socialists and factions of the Muslim League and several other parties). LDF and UDF have come to power in different elections since then, often in an alternating manner (at present, the state has an LDF rule). The communist politics of Kerala and the 'miracle' of Kerala development model have both received international attention, and also critique (see Nossiter, 1982; Ratcliffe, 1978; Mencher, 1980). In 1996, the CPI-M led LDF coalition launched the 'People's Campaign for Decentralized Planning', which has been an important project of decentralisation of governance and participatory decision-making (see Törnquist, 2001; Heller \& Isaac, 2005), and brought substantive changes over time (Anil, 2020). Among Indian states, Kerala also tops the performance on sustainable development goals. As the narrative above indicates, Kerala political and developmental economic performance is an outlier in several ways.

In the decades leading up to the Indian independence, communism and nationalism proved to be significant ideological forces. While the top leadership of Congress and the Communists reflected the influence of individuals from upper caste or elite Hindu backgrounds, the class struggle of the peasants and the landless against power, property and police ${ }^{5}$ was the backbone of the communist spread. The brutalities carried out by the police and the landlords had paved way for the spread and subsequent dominance of communism in the villages of north Kerala, where the poor tenants and agricultural labourers organized under the Communist party, agitated, were also killed in many villages. These villages later came to be called revolutionary villages (Kurup, 1985). As a result of this political conflict in the 1950s and 60s, intense struggles between party and anti-party dynamics unfolded in Kerala over the decades that followed. In north Kerala - the region specifically marked by the histories of caste oppression, concentration of land ownership with elite Hindu upper castes, peasant revolt and a mix of anticolonial, nationalist, and Communist mobilisation - the desire to succeed in electoral competition produced what have come to be known colloquially as party gramams. This 'party village' is an administrative unit from where a particular political party dominates all lived experience and from where it does not, indeed cannot, lose elections. It is a demarcated area of influence and control of a particular political party, which might at first glance seem similar to a 'political stronghold' or a 'pocket borough'. However, in

\footnotetext{
${ }^{4}$ Important background events to these years are the 1962 war between China and India, and the SinoSoviet split in that same decade.

5 The Indian National Congress (INC) activists who were mostly landowners, the feudal landlords, the armed police of the Madras Presidency and the Malabar Special Police (MSP) were all part of the other side of the revolutionary communist political struggle, whereas caste hierarchy and communal forces were distributed across the groups.
} 
contradistinction to those terms, the 'party village' is neither overly small nor defined only by the electoral result. Political strongholds in a territorial basin are a necessary but not a sufficient condition for an area to be understood as a 'party village'. This is because, in addition to political loyalty, political dynamics, visual appearance and everyday life of people and place in a party village are all tied together into demonstrable and unquestioning support for one particular party. Thus, not only can the Communist Party not lose elections from a specific Communist Party village, the visual symbols painted everywhere and even the choice of colour and clothes people wear reflects allegiance to the Communist Party. While an opposition party can formally contest from such a village, they cannot campaign critically or openly mobilise supporters, without inviting intimidation or political killing. Party villages are a unique phenomenon to north Kerala (Malabar region), specifically the Kannur district. ${ }^{6}$ Party villages are not exclusively Communist, though most of them are Communist, ${ }^{7}$ and the Communist party villages in Kannur are where all aspects of life are overwhelmingly dominated by the party. These villages also have "martyr squares, ${ }^{8}$ which are monuments to the political workers of the dominant party killed in the inter-party clashes.

There are hardly any detailed studies of this peculiar and unconventional democratic dynamic, and officially, party villages do not exist, though they are referred to as party gramams in popular parlance. While every party denies using intimidation, ostracisation or political violence in order to enforce their dominance over the party villages, they all do. The political parties suggest that these villages are simply areas where they have a strong support base and people choose to conform to the party symbolism out of affinity and affection. Of the few national media reports that appear about the party villages, usually at the time of elections (Devasia, 2016; Lobo, 2017; Menon \& Sudhakaran, 2016; Shahina, 2012), all emphasise the way in which everything from bus shelters to public wells to telephone and electricity poles and walls and buildings indicates the colour and symbolism of the party that dominates the village. This also extends to how and with whom people fraternise, hold marriages and funeral ceremonies, and even what people may wear in any party village (for political meaning of colour in contemporary Kerala, see Kannangara \&

\footnotetext{
${ }^{6}$ Party villages are thus distinct from, and not to be conflated with, what Bhattacharyya (2009: 60, 69) defines as 'party society' or 'the specific form of political society in West Bengal's countryside', and which he sees as 'a big step in democratising rural politics'.

7 By most reckoning, Kannur has about 50 party villages, a majority of them Communist. There are RSS/BJP (Rashtriya Swayamsevak Sangh/Bharatiya Janata Party — RSS is the right wing Hindu militant ideological parental organisation of the BJP, a party ruling at the centre in India since 2014 (for a historical context on RSS, see Curran, 1950), Muslim League (ML) and Congress strongholds in Kerala, but the Communist party villages are distinctive because (a) the Party dominates all life in such villages and (b) the contrast a Communist party village presents of existing egalitarian ideologies and caste hierarchies (unlike non-revolutionary or regressive parties where we might predict the accommodation between BJP/RSS and regressive social conservatism). Our work in this area continues, and in the future, we hope to provide comparative studies of RSS/BJP and ML villages.

8 The idea of sacrifice is apparent in the choice of terminology. CPI-M victims (both in the historic revolutionary struggle and in later inter-party conflict) are termed 'martyrs', and the BJP/RSS victims are termed 'balidanis' (literally, 'those who sacrifice'). See news reports such as Devasia, 2016.
} 
Devarapalli, 2019). Those who do not support the party dominant in the village can live in those villages, but so long as they do not offend the dominant party: "peace prevails when we offer no resistance' (words of a Congressman in a Communist CPI-M Panchayat, quoted in Shahina, 2012). In addition to the documentation of political violence and killings in party villages, there are also indications of electoral malpractices such as bogus voting. For the people in these villages, the dominant party ensures welfare and government benefit in return for unswerving political loyalty. Owing to the fact that a majority of the party villages are Communist (CPI-M led LDF being the coalition that gains power), UDF (Congress-led coalition) and the BJP/RSS make mention of their intentions to 'liberate' these villages; on the other hand, the Communists submit that the framework of party villages is part of 'right wing propaganda'. What is undeniable, however, is the empirical evidence of political violence in Kannur over the years (see Ullekh, 2018). Chaturvedi (2015: 164) writes that since the late 1970s, 'more than 4000 workers of the Left and Hindu Right have been tried for acts ranging from criminal intimidation, attempt to murder and murder of members of the opposing party'. Further, Chaturvedi (2017) writes that according to police records between 1983 and September 2009, there were 91 murders in political cases, repeating the intense period between 1978 and 1981 when around 30-40 workers of CPI-M and RSS-BJP were killed.

\section{Che Puram Village: Caste, Resources, Political Allegiances}

Che Puram is a village dominated by the Communist Party of India-Marxist (CPIM). Che Puram has never elected a candidate of any other political party than the CPI-M or its allies. The Grama Panchayat (village council) to which Che Puram belongs to has 14 wards. All these wards have been represented by the CPI-M and the grand old Left Democratic Front (LDF) alliance since the formation of CPI-M in 1964. The undivided CPI before had ruled the Grama Panchayat without any opposition. In spite of this unbroken political record of success by a party with an egalitarian ideology in the village, there is a simultaneous continuation of a caste hierarchy rooted in the Hindu religion. Che Puram is the site we focus on to examine the anthropology of democratic dynamics and the CPI-M in Kerala.

In Table 1, we present an overview of the village castes and social hierarchy. Brahmins still have an upper hand in shaping the Che Puram village society with its social, caste and communal intricacies. All of the many rituals here are mythically interpreted and performed in the presence of Brahmins, who restrict themselves from attending any rituals of castes lower than Nairs. In their mythologies, Brahmins have always been illustrated as the 'superior ones'. The collective psyche of the village has absorbed this mythico-ritualistic tradition, and the worshipping centres were eventually divided into two: the Devalayam and the Bhoothalayam. The Devalayam is the temple where Brahmins conduct pooja (prayer service), and Bhoothalayams are shrines where indigenous gods are worshipped by the shaman or a non-Brahmin priest. While milk, banana and flowers are offered to the deities in Devalayams; dried fish, blood of hens and toddy are very common offerings in Bhoothalayams. The Namboothiri Brahmins in Che Puram do not have visible political loyalties, but 
Table 1 Caste and social hierarchy in the village

\begin{tabular}{|c|c|c|}
\hline Caste name & No. of households & $\begin{array}{l}\text { Average land per } \\
\text { household (in } \\
\text { cents) }\end{array}$ \\
\hline Namboothiri Brahmin & 50 & $200-500$ \\
\hline Gauda Saraswati Brahmin & 12 & $10-25$ \\
\hline Nambi & 20 & $20-40$ \\
\hline Nambeeshan & 14 & $20-40$ \\
\hline Unithiri & 21 & $100-300$ \\
\hline $\begin{array}{l}\text { Nambiar } \\
\text { Adiyodi } \\
\text { Pothuval } \\
\text { Kurup } \\
\text { Other Nairs }\end{array}$ & $\begin{array}{l}210 \text { (Total for } \\
\text { Nairs including } \\
\text { Nambiar, Adi- } \\
\text { yodi, Pothuval, } \\
\text { Kurup, Other } \\
\text { Nairs) }\end{array}$ & $\begin{array}{l}\text { 50-200 (Total for } \\
\text { Nambiar, Adi- } \\
\text { yodi, Pothuval, } \\
\text { Kurup, Other } \\
\text { Nairs) }\end{array}$ \\
\hline Maniyani & 110 & $50-200$ \\
\hline Moovari & 35 & $20-40$ \\
\hline Vanniya & 250 & $20-40$ \\
\hline Thiyya & 320 & $15-30$ \\
\hline Mooshari & 24 (Total for & $5-10$ \\
\hline Ashari & Mooshari, & $5-10$ \\
\hline Thattan & Kollan) & $5-10$ \\
\hline Kollan & & $5-10$ \\
\hline Chaliya & 200 & $5-12$ \\
\hline Kaniyan & 11 & $15-30$ \\
\hline Kavuthiyan & 12 & $5-10$ \\
\hline Vannan & 16 & $5-12$ \\
\hline Mukuan & 18 & $5-10$ \\
\hline Malayan & 18 & $5-10$ \\
\hline Mavilan & 15 & $5-12$ \\
\hline Pulaya & 65 & 4 \\
\hline Chakliya & 65 & 4 \\
\hline
\end{tabular}

As a unit of land holding in south India, a cent is an area equivalent to one-hundredth of an acre

according to the communists, one or two people among the community were active in CPI-M, and the rest were sympathizers of the Indian National Congress (INC). A few have recently started showing a great interest in the BJP.

In the existing hierarchical caste order of Che Puram, Nambi, Unithiri and Nambeeshan come next to the Brahmins. They have traditionally been household and temple gofers of the Brahmin community. Their habitats are located near the Namboothiri settlements and temples. Since they have close occupational relationships with Brahmins, they hold high privileges in society. In the feudal era, a few families owned vast areas of land, and rich families from these communities leaned towards the INC (Congress), while the educated radicals and people from poor families supported the Communist Party. 
The village has a diverse visibility of the Nair caste that comes next in hierarchy, with sub-castes like Adiyodi, Kurup, Pothuval and Nambiar. When the feudal social structure was in place, the majority of land was owned by the oligarchy composed of Chirakkal Kovilakam (a prominent dynastic family seat of north Kerala), Namboothiri Brahmins and temples, and the Nairs largely took care of the formers' agricultural production. As a result, the Nairs too emerged as aristocrats. In Che Puram, the Nair households are consolidated in Puthoor, Kuniyan and Paliyeri areas with the large paddy fields of the village. The social status of each sub-caste among Nairs differs according to their socio-economic conditions. The Adiyodi, Kurup and Nambiyar have a higher status. Some Nair families in Che Puram previously had their own worshipping spots named Kavus, which were later transformed into temples where Namboothiri Brahmins conducted their daily poojas. Some of these temples are now run by a committee of village people supported by the CPI-M. The INC finds its supporters mainly from traditional aristocratic Nair families, in contrast to the poor cultivating Nairs who have prominent positions in the CPI-M. The Nairs are more visible in public life, unlike the Namboothiri Brahmins, and they hold leading positions in political parties and cultural organizations.

Maniyani is another prominent caste in Che Puram, placed just below Nairs in the caste hierarchy. Historian Dilip Menon (1994) had observed the origin of Maniyani caste to a tribe that assisted Nairs in land cultivation. Gradually, they were assimilated into the caste system. They still practise agriculture, masonry works, and some of them rear cattle too. The most prominent person in the context of modern Che Puram and the founder of the Communist party in the village - the late A. V Kunjambu - belongs to Maniyani community. A majority of the Maniyani people are loyalists of the CPI-M in the village.

Traditional oil makers of the Vaniya caste come next in the hierarchy. The Vaniya community is the second largest caste group in Che Puram. They account for around $30 \%$ of the population and have a scattered visibility in the village, however, the Vaniyas have profound visibility in the public sphere of the village, and a significant majority of them are communists.

Thiyya, the largest caste in Che Puram, is placed next in the caste hierarchy. Thiyya is one of the numerically dominant castes in entire north Kerala, like their counterparts the Ezhava in southern Kerala. Thiyyas were treated as 'untouchables' during the era of feudal prevalence. They were largely sidelined by the INC (Congress) and commanded by the upper caste landlords. It is for this reason that the Thiyyas were strongly against the INC (Moyarath, 2012), and this had paved the way for the rapid spread of the ideology of Communism and the growth of CPI-M among the community. The Thiyyas are the backbone of the Communist party in Che Puram. Even though many local Communist leaders are Nairs, it is the Thiyyas that form a big chunk of the branch committee members. Their history of involvement with the Communist Party provides the Thiyyas with a deep and satisfying sense of commitment. There are a number of First Investigative Reports (FIRs) filed against the local Thiyyas at the police station, a fact to which an elder Communist leader named Raghavan responded thus: 'We have the spirit of communism in our blood. We protect the party in any situation by any means'. 
Che Puram village has a few families of the Ashari (the carpenters), Kollan (the blacksmiths), Thattan (the goldsmiths) and Mooshari (the coppersmith) communities. Together, they are called the Vishwa Karama community and were an integral part of the agrarian feudal system. These castes form around 32 families. Among these caste groups, there are families and individuals who support both the INC and CPI-M.

Chaliya, the traditional weavers, come next in the caste hierarchy. They live in small houses built next to one another in an area normally called Theru or Chaliya Theru. Che Puram too has a Theru (settlement) where approximately 200 families of the Chaliya community live. Most of their houses are small sheds with traditional weaving instruments and cotton materials inside, and many from the community still pursue weaving, making largely handloom dhotis (unstitched cloth covering the lower body from hips to toes). Although the Chaliyas in Che Puram generally support the CPI-M, they do not have much representation in the party leadership.

The Vannans and Malayans are traditional Theyyam dancers of Che Puram. The Theyyam is a folk ritual of worship including song, dance and music, which is intimately connected to the socio-cultural identity of North Malabar (see Kavitha, 2019 for power politics in the Theyyam). These underprivileged communities also go for various daily jobs in the village. There are approximately 23 families of Vannans in Che Puram. They live along with the middle caste groups such as Nair, Maniyani, Vaniya and Thiyya in localities like Paliyeri, Kuniyan and Manakkattu. Ironically, though they perform the godly rituals for upper castes, Vannans are deprived of every other upper caste privilege. Their political loyalties are affected by local personal and also livelihood ties and are thus divided between Congress (INC) and the CPI-M, but without overt participation in political events.

There are seven colonies on the fringes of Che Puram, reminiscent of ghettos. In Kookanam, Palakkunu and Pranthachal, the 240 Chakliya people live in 65 households. These small houses are single rooms built on government-granted aid of four cents of land. Around 320 Pulaya people live in 65 households (in conditions similar to those of the Chakliya people) in four other colonies located at Pulakkunnu, Marathankanda, Muringattu and Palathara. The Pulayas were 'untouchables' and agricultural labourers during the feudal era. They belonged to the bottom rung of the caste order and were thus denied all rights and made to toil on farmlands. ${ }^{9}$ The Chakliyas are traditional leather-makers who migrated from the nearby state of Karnataka. They still speak a different dialect with a mix of Malayalam and Kannada languages. They no longer pursue their traditional occupation, opting instead for minor profitable jobs (for example, some sell dolls and balloons at festivals). The Pulayas are traditionally agricultural labourers, but most of them in the younger

\footnotetext{
${ }^{9}$ Even as late as 1960, texts about Pulayas placed much of the responsibility for their ill-treatment upon their 'backwardness', suggesting that they had to change their behaviours and improve their position in order to 'get accepted as social equals by persons from higher castes' (see Alexander, 1968: 1073). Mannathukkaren (2013: 508) provides a discussion of how the communist movement never overcame its paternal attitude to caste whereby the Dalits and indigenous people were to be 'led by' the upper caste communist leaders; Menon (1999) particularly argues that communist cultural agenda refurbished caste-elitism as high culture of the developmental modern self.
} 
generation now perform all kinds of labour work in the village. The Chakliya and Pulaya communities support the CPI-M. As Koran, an elder Pulaya from Muringattu colony, told one of the authors: 'CPI-M is the only party that helps us and whenever we have a problem, we approach the party to help us, but there are no party members among us'.

The list of the Communist party members in the North local committee ${ }^{10}$ of Che Puram village is provided below. From Table 2, it is evident that a consolidation among the middle strata of the caste hierarchy ensures the smooth functioning of the Communist party in Che Puram, even as people from other castes and religions are not members of the party. ${ }^{11}$

Table 2 Communist Party members in the local committee

\begin{tabular}{lll}
\hline Position & Caste & Religion \\
\hline Local Secretary & Nair & Hindu \\
Member & Thiyya & Hindu \\
Member (F) & Vannan & Hindu \\
Member & Chaliya & Hindu \\
Member (F) & Chaliya & Hindu \\
Member & Chaliya & Hindu \\
Member & Maniyani & Hindu \\
Member & Maniyani & Hindu \\
Member & Thiyya & Hindu \\
Member & Thiyya & Hindu \\
Member (F) & Thiyya & Hindu \\
Member & Thiyya & Hindu \\
Member & Thiyya & Hindu \\
Member & Vanniya & Hindu \\
\hline
\end{tabular}

There are 3 women in the list, marked as $(\mathrm{F})$. Politics in the village is largely controlled by men. Women are seen in political processions, campaigning and other activities, but during the fieldwork, women were observed to be working under the directions of the male leaders. The village has a unit of the All India Democratic Women's Association, which functions independently. However, Che Puram does not claim any prominent women leaders

\footnotetext{
10 This committee is the higher authority formed from the branch committees of Kookkanam Central, Kookanam North, Kookanam South, Paliyeri Kovoil, Paliyeri, Vellavazhal, Cherumoola, Palakkunnu, Annoor, Naduvappuram, Theru, Manakkadu North, Manakkadu South and Mannakadu Central.

11 There are around 36 Muslim families in Che Puram, majority of whom support the communist party. Among the Muslims, there are some people who support the Muslim League and other Muslim organizations, but do not profess this allegiance in public as it is a communist party village where Muslim league cannot function openly. There are around 6 Christian families, with divided political loyalties.
} 


\section{The Che Puram Paradox: Caste, Hierarchy and Everyday Politics}

The hierarchical caste system has been one of the key components of the social structure of Che Puram since the arrival of Namboothiri Brahmins probably in the eighth century (Unithiri, 2005). Brahmins are credited with the introduction of this feudal social structure termed caste. They placed themselves at the top of this hierarchical social order, based upon which a concrete feudal system emerged in Kerala. From the tenth century, feudalism had remained the main political and social system until the colonial period. Everyone was subjected to this rule, and the lives of people were (are?) shaped by its customs. A numerically minor group of Brahmins oppressed and controlled a large population largely involved in manifest manual skills. Viewing these power relations in a feudal social structure through a Foucaultian notion of power/knowledge, we might see how the knowledge that the Brahmins produced envisages and to a great extent creates the village social relations. And this same knowledge makes the Brahmins a privileged and powerful community at the top of the order and subjugating all others who are part of that society.

Manufacturing this knowledge mainly through religion creates a social structure helmed by Brahmanical dominance where whoever else internalizes the logic is subjugated to the latter. Brahmins and other subordinate castes believed that this knowledge was the former's power to maintain the caste structure. These days caste operates and exists in the structure rather than its old feudal forms of physical discrimination. The caste system survives because the knowledge of caste still prevails and is still perceived by the people. The myths, rituals and appropriations are the fundamental tools that the Brahmins utilized to dominate over the other communities. And the power of the Brahmanical religious apparatuses is profound in Che Puram even now in the time of a democratic political set up.

Fieldwork observations indicated that many communist party leaders prefer to keep silent when confronted with questions about the prevailing caste practices in the village. The communists refuse to see things through the prism of caste but also remain unable/unwilling resisting the hierarchy's institutionalised dictates. The upper castes and lower castes have different reasons for not wanting to talk about the social relations of the caste system. The upper caste people proudly vocalise about their caste identity but deny the existence of any kind of caste-related practices. The lower caste people hesitate to talk about the caste system, or give a normalizing view about the caste order and its practices. Yet, caste is present everywhere in the everyday life of the village people. Bourdieu has argued that 'every established order tends to produce (to very different degrees and with very different means) the naturalization of its own arbitrariness' (Bourdieu, 1977: 164). People from both top and bottom of the caste hierarchy may resist any attempts critiquing the existence of this hierarchy with same rigour. Thus, the Brahmanical supremacy is maintained through the 'mythico-ritual system' (ibid.), which deeply influences the democratic political settings of Che Puram. In this section, we narrate some instances that illustrate the working of the mythico-ritual system in Che Puram in reproducing the hierarchical caste structures. 
The Paliyeri Sri Mookambika Devi temple is one of the most popular temples in the village where all Hindus - except the lower caste Pulaya and Chakliya — have visited for the last twenty years. It was a sacred grove popularly called Kavu, and people mainly remember it as Thaduppa Kulangara Kavu, which was later changed to the current temple. This change in its name and functioning (change of ownership from family to public trust ownership) had happened twenty years ago. A special gathering named Preshanam Vерри (astrological enquiry) was organized to understand the reason behind some mishaps around the temple. Preshanam Vерри was conducted by a Brahmin priest, and he found a few things that had brought bad luck to the people around primarily the fact that no daily pooja worship was conducted in the temple, and this had made the Devi goddess unhappy. The priest advised the devotees to renovate the Kavu with new light lamps and conduct Hindu Navarathri festival every year. The Nair family who owned the Kavu could not afford to conduct the daily pooja and appoint a Brahmin priest. So, a committee of devotees, consisting mainly of upper castes, had decided to take over the committee from the family. They converted the Kavu into a temple, renamed it as Paliyeri Sri Mookambika Devi temple and opened it to the public. At this time, a daily pooja and annual festival had both begun. A majority of members involved in the managing body of the temple belong to the Nair community, which supports the Communist party, and a Namboothiri Brahmin has the rights to conduct the poojas.

The temple has multiple deities. Mookambika Devi was installed in the Kavu in the sixteenth century when Brahmanism had deeply influenced the local belief system (Kannangara, 2018). There is an idol of a snake named Naga Prathishta, representing a kind of animism that exists among the Nair community of north Kerala. There is also Virajadan, a deity worshipped once a year with the performance of a shaman (the Theyyakaran in local terms). The worshiping associated with Virajadan is not Brahmanical but rather similar to a kind of shamanism that exists among some societies in Kerala. A man performs a dance with songs and drum-beats in front of the deity, and later the spirit of Virajadan enters the idol first, and then, the performer. People start praying once this happens, and this continues for a long while. Both these deities have been part of a primordial religion that existed in pre-Dravidian and Dravidian societies in Kerala. Brahmins eventually appropriated these indigenous religions into a broader Hindu system. Myth-making and assimilation were the cultural tools which enabled this process over time.

Jithin is a twenty-four-year-old man of the Nair caste who never misses visiting the Sri Mookambika temple at Paliyeri in Che Puram during the Navarathri festival $^{12}$ in October. He works for a software developing company in Dubai and had taken a short break to attend the festival when the second author met him. Jithin felt that a sudden sanction of leave from his office to be able to make the trip was a blessing from Mookambika Devi. Two days later, Jithin had to host another sacred ritual at his house. His friends and young acolytes in the village had gathered to help him organise this Muthappan Theyyam, an indigenous ritual performance that

\footnotetext{
12 The village witnesses a lot of rituals, ceremonies and cultural performances during the ten-day-long festival.
} 
would happen in the house courtyard. Muthappan is a legendary folk hero of North Kerala, and Muthappan Theyyam is a kind of spiritual worship and the most prominent among many Theyyam formats present. The Muthappan Theyyam is considered to be a rebellious deity since he loves meat, dried fish and toddy. This Theyyam is affectionately referred to as the 'Communist Theyyam' in many localities in north Kerala due to the rebellious aura around this deity in the folklore. ${ }^{13}$ Jithin had made a vow to host a Muthappan Theyyam in celebration of getting a job. In his own words, 'It is because of Muthappan that I got the job. One Muthappan had told me during a performance that I would get a job soon and I should always keep Muthappan in my prayers for the favour.' The performance began by 11:20 P.M. and the red-robed performer started chanting mantras; soon, he embodied the spirit of Muthappan and became Muthappan Theyyam. There was a sudden transformation of ambience in the courtyard, which was understood now as sanctified. People approached the Muthappan one by one and listened with utmost respect to his directions and blessings.

Later that afternoon, Jithin and his friends appeared on the street to organise a public event of the Democratic Youth Federation of India (DYFI) - the youth wing of CPI-M - Paliyeri village committee. The event was part of a state-wide program organized by the DYFI against rising incidents of communal attacks and authoritarian policies of the BJP government at the centre. The loudspeaker broadcast revolutionary songs, in ritualistic initiation of a communist public program.

You gave us, a better tomorrow and then you were gone.

You are the courageous heroes-

Who left everything for this land.

Comrades, you wrote epics with bloodsheds,

We will never forget you martyrs,

Lal salaam comrades,

lal salaam, lal salaam...

[Red Salute, comrades].

The lyrics of such songs express the struggles of many communist comrades against the feudal landlords during the 1940s. As we mentioned in the first section, the communist movement was a powerful political agency with a particular genesis in Kerala. In Che Puram village, five peasants were killed in police firing on December 20, 1946 when they resisted the move of the landlords and police to transport paddy away from the village, even as the village was reeling under the influence of a famine created by the Second World War and the exploitation of landlords. This event is known as the Che Puram incident in Kerala Communist party's history and had a significant role in enabling the village to become a party village (party gramam). At the DYFI event, the key speaker reinforced the significance of this memory for the history and political psyche of the village:

\footnotetext{
13 The role of Muthappan in the growth of Communist party in North Kerala is yet to be explored. Parashinikadavu Muthappan Temple in Kannur is one of the prominent shrines in north Kerala, and it has been under the CPI-M backed trustees for a long time.
} 
Dear comrades, brothers, friends, and dear people. I am so glad to stand here in front of you because, I know this place. It has a history, a history of blood. This is a village where many comrades had lost their life during a staunch resistance against feudal landlords. Communism still lives in our blood and we will let it live till our death.

Jithin was an active part of the temple festival, the Theyyam performance, and the political programme over a few days. The social structures and processes of socialisation are reflected in the different aspects of his identity. Mark and Verien (2008) refer to the ways in which selection and active memberships of groups that people want to identify with are always constrained by structure. Like many other upper caste people in Che Puram, Jithin believes in Brahmanical Hindu gods like Mookambika Devi (the primary deity of Paliyeri Sri Mookambika Devi temple) and Lord Shiva (the deity of the oldest temple in Che Puram). He also believes in the socalled indigenous religion or sacred performances that are called Theyyams, which have endured as a remnant of the indigenous pre-Dravidian and Dravidian societies that had lived in the village before the arrival of Brahmins. ${ }^{14}$ In addition, Jithin is a committed and proud communist:

May be my family is the primary reason that I became a communist. My grandfather belonged to the first generation of communists in the village. My father has always told me that the communists constantly fought against the landlords for food and to protect the rights of poor peasants. The landlords and their police had often tortured them and we at last got a nice life through their sufferings. All of my four uncles and three aunts still support the Communist party and the local and branch committee leaders belong to our family. I was the unit secretary of Balasangam, a children's organization affiliated to the CPI-M, when I was ten. Though family was the first reason that I became a communist, Balasangam helped orienting many of our political and organizational behaviours. I had worked for Students' Federation of India (SFI), the student wing of CPI-M, during my college days. Those days had clearly shaped my political psyche and I began actively working for DYFI after my college. DYFI is the most vibrant organization that engages in solving the social problems of the villagers.

The complex role of social processes in identity formation and its maintenance or modification as a result of social structures has been the subject of much work (for instance, Berger \& Luckmann, 1966). The CPI-M gets political benefit across the caste spectrum from the Namboothiri Brahmins to the lower castes of Chakliya and Pulaya. The Brahmins are relatively affluent and smaller in number, so the visibility in party politics is not a useful tool for them; the shift in political power to mediatory castes over the twentieth century provides a solid base to the communist party, which cannot be challenged by those lower down in the caste hierarchy. Almost

\footnotetext{
14 'The hierarchical caste based Hindu religion had reached the village in the medieval period, probably during the tenth century', according to Murali, a local historian.
} 
everyone in the village has stories like Jithin's about the evolution of their political identity. The structural complexity of the social world of Che Puram is apparent in the coexistence of Brahmanical Hindu religious apparatus and the Communist ideological apparatus, both of which dominate in the village.

The dominance of CPI-M in the local elections is correlated to its ideological accommodations with the regressive hierarchies of caste and religion. An ex-local committee member of CPI-M, Comrade Krishnan, narrated a love marriage controversy in the village from a few decades ago. His friend, Comrade Narayanan, a Nair by caste and a school teacher by profession, was the local committee secretary of CPI-M. All his family members were well-educated and committed communist workers. His elder son, an activist of the left-wing SFI (Students' Federation of India), had an affair with a Muslim girl who was also an SFI activist. Upon securing jobs, the couple had approached his family with a proposal for marriage, but Comrade Narayanan would not accept it. He asked his son to leave the house if he wanted to marry a Muslim. Finally, Narayanan's son approached the CPI-M Kannur district committee for help. M.V. Raghavan, the General Secretary at that time, himself came to Che Puram to convince Narayanan and his family. Despite being one of the most popular and charismatic communist leaders of the time, M.V. Raghavan failed to convince a local leader. He was quite upset with the bias of Narayanan's family and later helped the couple to marry. The wedding took place in the party office of Kannur, and Narayanan's family cut ties with his son for a long time. Comrade Krishnan added that the village is not open to inter-caste marriages, although a few such had taken place. The story of Mohanan, a Vanniya man, is no different. He married a Thiyya woman around twenty-five years ago and was expelled from the Vanniya community, which has a strong in-group sense of community. The Theyyam from Muchilottu Kavu (a shrine belonging to the Vanniya community) has not entered his house since then. Yet, the same people who follow and control the norms of caste structure in Che Puram also largely support the Communist party with its progressive principles.

The cremation of Comrade Thamban in December 2015 was yet another case that made clear the paradox of Communist affiliations in the context of the structural situations in the village. Thamban was an influential local committee member of CPI-M who belonged to the Thiyya caste. His family had refused to take his body to the public crematorium that was managed by CPI-M since it is mostly the landless Pulayas who were cremated there (all the other castes have their own caste crematoria). As a result, the body was taken to the Thiyya community's cemetery and cremated with religious customs.

\section{The Communist Party Apparatuses}

As the Brahmins use myths and rituals to maintain their cultural hegemony, the Communist party too uses various apparatuses to maintain their territorial and political dominance in the village. These include, to borrow terms from Althusser (2001 
[1970]), the Ideological State Apparatus (ISA) and Repressive State Apparatus (RSA); the former functions by ideology, and the latter predominantly by repression (including physical repression), and secondarily through ideology. ${ }^{15}$ In this section, we seek to understand the paradoxical co-existence of the Communist party, religion and its hierarchical caste practices in the village by drawing attention the functioning of such apparatuses.

Hindu religion has a strong presence in the village, but its institutions are controlled by the Communist party. In the words of Comrade Krishnan, 'It is a decision taken by the Communist Party to take control of the temples through active involvement even in the annual festivals to resist the infiltration of right-wing Hindu organisations like RSS and BJP'. The main reason given for this control of temples is that the temples and religious festivals are the major political instruments through which the RSS and BJP mobilise Hindu people everywhere. Indeed, it is the case that political use of Hindu identity, 'Hindutva', is central to BJP/RSS, who use it to consolidate the categorically divided caste communities and create the monolithic notion of Hindu religion to benefit in the right-wing majoritarian project of RSS/ BJP. ${ }^{16}$ In Che Puram, we observe that the Communist party has been successful in utilising religion as part of its apparatus to mobilise people, while legitimising this as a way of protecting the village from BJP/RSS' use of religion, and also simultaneously accommodating to the regressive hierarchies of religion.

As we noted in Jithin's narrative, the family is a key locus of communist sympathies for many people, and the institution of the family is utilized for political socialization in the village. The Communist party in Che Puram has a system of keeping different levels of interactions with families according to their political affiliation. The Communist party recognises four types of families in the village. The party gives highest priority to Martyrs' families, i.e. families of those who lost their lives for the Communist political cause. These families are believed to be the party's assets and are kept safe. They are also given funds and jobs in institutions under Communist control. The families of party activists or office bearers who take part in the daily activities are the second category of families recognised by the party. The third category consists of families of party sympathisers who are not active party workers but keep in close touch with the organisation. They refresh their relations with the party by offering donations, and the party keeps aware of the choices of these families for any elections. The party concerns itself with the welfare of these three kinds of families and often extends a helping hand during crises. Families who are politically neutral or are supporters of any other parties come under the fourth type of families. The CPI-M usually does not keep any political relations with this fourth type and sometimes boycotts them in social circles.

\footnotetext{
15 There is no such thing as a purely repressive apparatus. For example, the army and the police also function through ideology in order to ensure their own cohesion and role in society. The Ideological Apparatuses function predominantly by ideology and secondarily by repression. Althusser lists a number of institutions such as religion, education, family, legal system, trade union, media, clubs, etcetera through which ideological apparatus functions.

16 For more details about this project and its strategies in contemporary India, see Kaul (2017).
} 
The Communist party also acts as an interlocuter for people's everyday problems in interpersonal or institutional settings. Instances like a bus driver not stopping the vehicle at the designated stop or bus employees not letting students in are immediately taken up by the party. Through democratic means of protests (like dharnas or sit-ins), it takes up basic needs-based issues such as roads, drinking water and health problems. The party has dispute-resolution intermediaries who try to solve local conflicts. For instance, Comrade Krishnan Mash, a seventy-year-old man, was a local leader of Communist party in Che Puram for a long time (till his recent withdrawal from party responsibilities due to ill health); he acted as a prominent mediator in the village, and had a reputation for solving various forms of local disputes. This local legal system is especially useful for members when there is a dispute between them and someone from a rival political party.

Almost all political parties in the state use trade unions as a significant ideological apparatus. The Communist party, predictably, has a strong culture of forming trade unions since their basic ideas speak of liberation of the working class. Workers are mobilised to form unions across all the sectors, and the CITU (Centre of Indian Trade Unions) is an umbrella organisation of many trade unions associated with CPI-M across different trades. Che Puram was not an exception; Beedi (hand-rolled cigarettes) rollers, ${ }^{17}$ weavers, Khadi (spun cotton fabric) workers were mobilised back in the early 1940s, and their role in spreading the political agenda of the Communist party was crucial. The agricultural labourers of Che Puram are organised under Karshaka Sangam, the toddy tappers under Chethu Thozhilali Sahakarana Sangam, the weavers under Weavers Sahakarana Sangam, the dairy producers under Ksheera Karashaka Sangam, the head-load workers under Kayatirakku Thozhilaali Union, ${ }^{18}$ auto taxi drivers under Drivers' Union, masons under the Construction Workers' Union, and the barbers in the village are associated under the Barbers' Union. Workers assert their rights through trade unions, and this in turn contributes to the strength of the political parties. The strong presence of left-wing trade unions in the village helps the Communist party to assert its dominance.

The Communist party's mouthpiece in Malayalam, Deshabhimani Daily, is the most subscribed newspaper in the village. All the libraries and cultural associations under the party subscribe to the daily. People rely mainly on the party-owned newspaper and its TV Channel Kairali TV or Kairali People TV. ${ }^{19}$ The party workers keep a sharp and critical eye on other newspapers and TV channels. Buying subscriptions for Deshabhimani Daily for the families who keep a distance from the party is an act perceived with appreciation by many CPI-M workers. In Che Puram,

\footnotetext{
17 Though there were fewer people associated with Beedi trade in the initial days, small-scale units started emerging by the end of 1940 s in different parts of the village since the prospects of decent earnings were attractive. Both the authors visited such beedi rolling factories in the Che Puram village, which are staffed almost entirely by women.

18 In Kerala, the Nokku kooli (literally 'gawking wages') system was outlawed recently in 2018. This was an extortionist practice whereby headload workers would extract steep wages without doing any work. See Kerala Bureau (2018).

19 Both Kairali TV and Kairali People TV are owned by Malayalam Communication Limited, which has a larger share of support from communist sympathisers.
} 
the communication apparatus works through the wide circulation of the partycontrolled media outlets and the moulding of supreme faith on its content. Latest social media platforms like WhatsApp and Facebook are also used by the party for communication purposes in the village. Two Facebook groups and more than a dozen WhatsApp groups are active among the comrades, and all are used for mobilisation during any event in the village. The content of the communication not only throws light upon the political stance of the party but also criticism against other political parties.

There are a number of institutions which function as the cultural apparatuses for the party in Che Puram. These include theatres/drama clubs, village libraries, reading rooms, cultural/sport clubs ${ }^{20}$ and art societies. In earlier times, political plays vilifying landlords and the bourgeoisie were effective in spreading the ideology of communism in the village. The first written political play in Malayalam - Pattabakki (Balance of rent), by the Communist party founding leader K Damodaran (see George, 1958: 109) — was performed in Che Puram in 1939, the year it was written. Aiming to rouse the illiterate and impoverished masses with Marxist ideas, it depicted the exploitation that landless working people faced from the landlords. The Pattabakki had played a remarkable role in shaping the political psyche of the workers of Che Puram. ${ }^{21}$ The legacy of political theatre in Che Puram is upheld today through the collective of people including teachers, government employees, daily workers and students. The local clubs and other organizations under the Communist party often organize theatre programs along with political events. The Young Men clubs in Puthoor, Kookanam and Minarva of Che Puram too have been organising various arts and sports events in the village. All these clubs have a strong or relatively good connexion with the Communist party. While the plays performed during the early years of independence mostly featured the structural problems and inequalities in society, contemporary plays focus on electoral politics and banter about the opposition parties.

Along with the operation of ideological apparatuses, repressive apparatuses exist in the village to help the Communist party maintain its dominance. These work through various forms of physical and non-physical expressions of intolerance. In

\footnotetext{
20 There are many arts and sports clubs in Che Puram. The Young Men Club in 1956 in Onakkunnu was the first one. They regularly organised football and volleyball tournaments in the locality from 1957 to 1961. Many clubs were formed in the following years, and Aone club among them has a reputation for popularising badminton and reading culture. The club has an indoor stadium and a big library that people still use.

21 This information is sourced from Che Puram innallakal (Yesterday of Che Puram) published by CPI-M Che Puram committee. The Che Puram Kala Samithi, a theatre troupe formed by K. V Govindan, had staged plays named Thakarnna Tharavadu (Ruined joint family) and another named Karavatta Pashu by the pioneer of political theatre in Kerala K. T. Muhammad during the Indian Independence Day celebrations on 15 August 1953. Che Puram saw the emergence of another theatre group in 1957 with the formation of Udhaya Kalasamiti in Manakkad. Women had become more active in theatre for the next 2 years with Udhaya's arrival. In 1965, Deshabhimani Kalasamithi was formed in Pallikovil and staged Andhakaram (Darkness) first and had eventually performed Manushyavatharam (Human incarnation), Samudhayam (Community), Daivathinnu oru sent bhoomi (One cent land for the god) and Muganagal (Many faces). All these plays had radical political and social themes. The Central Arts Club formed at Onakkunnu in 1967 too staged similar types of plays.
} 
Che Puram, the repressive apparatuses can be seen to function in three ways. First, the comrades show intolerance towards any political or ideological differences, which often ends up in vandalism. Second, any alternative discourse challenging the party dominance is silenced at its origin when people ostracise or harass an individual who raises a counter-argument to an established norm. Third, the party has access to a useful lever in being able to withhold or disrupt the distribution of government welfare schemes to families who do not cooperate.

Repression strategies against Congress, BJP/RSS and other political parties are common in Che Puram. The INC (Congress) is one political party that works in the village and actively participates in all the elections. However, they are deprived of rights to public campaign such as sticking posters, organizing political programs and making loudspeaker announcements. Many comrades proudly boasted: 'Have you noticed that no other party's posters or flags are visible here? We have never let them do it and would destroy any new posters quickly. ${ }^{22}$ A senior Congress leader from the village, Ramachandran Nair, stated: 'The activities of INC in the village sometimes appear to me as a kind offering from communists since they need a weak opponent. So, we can contest in elections and we can sit in the polling station but we cannot campaign or challenge any attempt of CPI-M to cast proxy votes. I have seen many violent episodes of physical challenges for complaining against many of their illegal activities'. CPI-M also supresses any other budding ideological organisations in the village. The RSS began their Shakha ${ }^{23}$ in Puthoor area of Che Puram in early 2000. Some young men from the traditional upper-caste INC families were behind this new ideological development, but the party workers responded quickly and gave them an ultimatum to stop, which they eventually had to comply with. Both the aforementioned political outfits (INC and BJP/RSS) have a clear share of votes in the village, but they are not visible due to the informal curfew imposed by CPI-M.

The expectation of no deviation extends to the party members. An ex-CPI-M member in the village and a lower primary school teacher, Ravi, had been active in the youthwing of the party (DYFI) from a very young age but later deviated from the official line under the influence of a Marxist intellectual Professor MN Vijayan who took a critical stand against the party (see Seethi, 2007). A faction of dissenting intellectuals and workers formed a unit called the Invasion Resistance Front, which criticized the authority of CPI-M through literature and public programmes. Ravi tried to spread the views of the new outfit (led by MN Vijayan) among his friends and relatives in the village. In addition to usual pamphlet distributions and discussions, Ravi tried to organise a seminar but was interrupted by CPI-M. In Ravi's words: 'It is not possible to organize any program in the village even without the silent permission of CPI-M leadership. I once had tried to organise a film festival, but the hall owner backed off at the last moment saying it was not good for the party. I approached many other people but they all were already warned by the party.' Ravi began to be perceived as an irritant, and even his mother, who had utmost faith in, and loyalty to, the party, stopped talking to him. It was the Communist party, after all, that had procured a secure livelihood for her by means of a job in a Beedi

22 At the time of elections, it was difficult to find any sign of rival political party campaigns.

23 A 'shakha' or branch is the basic unit of RSS. 
rolling company when she had been left to fend for herself and four children after her husband's demise. The party had helped her through her struggles so that she could bring up her children, and then supported her children in finding jobs. Ravi's mother was fully convinced that her son had betrayed the party by working against its moral principles. ExComrade Ravi broke into tears as he narrated this episode. He had been isolated for his reactionary work, he had lost many friends, and he felt socially vulnerable. He felt that the party extracted its revenge by playing a part in getting him transferred to a school $63 \mathrm{~km}$ away from his village. He is now forced to stay away from the village for most of the day and returns from school at night.

\section{Concluding Thoughts: Looking Back, Looking Ahead}

Writing about north Kerala village politics in the mid-1960s, Gough ${ }^{24}$ acknowledged a puzzle: 'I am unable to explain why Trichur and Cannanore [Kannur], in particular, gained in Communist supporters... Communist strength is especially marked in Trichur, Palghat and Cannanore, where the Communists, already strong in 1960 , now have more than $50 \%$ of the total vote in the constituencies where the Leftists chose to run...' She further speculated:

One possibility which occurred to me was that there might have been intimidation of Communist supporters in this region. Shortly after the 1960 elections, A. K. Gopalan wrote a pamphlet, 'Rule of Terror in Central Travancore'. It described numerous murders, burnings of houses, beatings and other forms of intimidation by Congress supporters and the police against Communist supporters just before and after the elections.

Political violence against the 'anti-party' in Kannur is obviously not new, but between the 1960s and now, the specific and systematic territorial demarcations that emerged in the form of the 'party villages' are the focus of our analysis in this article. Our work brings together political analysis and ethnographic observation, across the disciplines of politics and anthropology that we draw upon. We began by situating the specific and rather unique political and social context of Kerala and its party politics in the wider literature, and then highlighted the social conditions and structural paradoxes of Che Puram as a communist party village. In this final section, we look back at key observations about north Kerala village politics in the 1960s and then offer theoretical insights based upon the contrast with our own analysis in contemporary times.

Gough wrote a twin set of articles (1965a, b) examining village politics in Kerala, based on her fieldwork visits there in 1948-1949, and then again in 1964. These articles (both written after the second visit in 1964) provide a snapshot of the village level society and politics as they existed prior to the coming into being of the 'party villages'. From these we draw together a few original findings relevant to our analysis. First, the

\footnotetext{
${ }^{24}$ The work of Kathleen Gough in the state over this period provides detailed analyses of the ongoing changes in Kerala politics (for an overview of her contributions to the study of Kerala, see Gough et al., 1993, see also Mencher, 1993).
} 
Communist party (and the Congress) had steadily expanded between the 1940s and 1960s, and while both parties had units in a village, the Congress had a larger number of enrolled supporters but fewer firm supporters, whereas the Communist Party had fewer party members in the village but a large number of followers. Second, along with the steady increase in enrolment in both parties, and similar political tasks allocated to the party units, there was a relatively greater sense of commitment evinced by the Communist party workers, who were also members of Communist labour unions that waged the most uncompromising struggles. Congress unions were seen as management unions, and factory owners were almost all Congress supporters. Third, favouritism, personal influence and distribution of scarce resources through jobs or contracts were common to the appeal of both parties, but the scale of corruption was different: 'Congress members are more often initially engaged in substantial private business than are Communists, and so have far greater access to government contracts and the 'gravy' that comes with them' (1965b: 414, italics original). Fourth, both parties had different underlying ideologies and class bases: Congress canvassing appealed to self-interest and incrementalist traditional public welfare, while Communist canvassing appealed to the class interests of the propertyless and for radical changes leading to greater economic and social equality. For the propertyless, favours or good personal relations were a primary factor for Congress support, while Communist supporters joined for ideological reasons and benefit to their class. In general, the assumption in the villages was that propertyowners, and those who have special relations with them, will support the Congress, and the rest of the propertyless, the Communists. Fifth, the top Communist leaders in the villages came from ancient high-caste families who were formerly prominent landlords and village headmen; these men from orthodox families had subjected themselves to party discipline, and in spite, or perhaps because, of having lost land to newer capitalist classes and merchants, they identified with the poor. Congress, on the other hand, had co-opted the rural gentry after independence. Newer types of supporters of both parties were emerging: the Communist supporter lacking aristocratic traditions and revolutionary experience of previous high caste mentors (locally born educated people from different castes and professions) and the influential rise of new Congress supporters who were capital owners (bankers, merchants, industrialists and export crop planters, often Christians or 'upstart' Hindus). Sixth, the Communist follow$\mathrm{ers}^{25}$ had a definite party allegiance, and one that they had maintained over a number of years. They owed allegiance above caste or community to the Party and its agenda of abolishing inter-caste competition and social inequalities; they were the ones who largely challenged Hindu religious and upper caste sanctions in the social domain. ${ }^{26}$

\footnotetext{
${ }^{25}$ She observed a number of people who had switched from Congress to Communist, but none who had shifted from Communist to the Congress since 1957. Party allegiance was defined as 'the party for which a man said he voted in the state and national elections, or for which he has reliably reported to work'. She uses the word 'man' advisedly, noting that 'I found it more difficult to discover the political allegiances of women. Most women are said to vote as their husbands or other close kinsmen do, but I'm not sure how true this is' (Gough, 1965b: 414).

26 She notes a group of young Communist mill-workers who sit in low-caste tea shops, play cards on the road and attempted to test the Temple Entry Act by bathing together in the village temple tank. They were condemned as 'crazy and sinful' by most Nayars (an upper caste Hindu group, described as traditionally landed aristocracy of government servants and religious specialists), and 'when a slimy, noxious
} 
As a result, two problems were beginning to be faced by the Communist Party: one was about the way to confront the communalism among poorer classes of Muslims and Christians who were more influenced by their own religious leaders, and another was the problem of explaining electoral political alliances (such as between the Muslim League and Communists) to the people during elections alongside the ideological differences between the elections. Gough (1965b: 415) quotes a Leftist thus: 'Electoral alliances freeze the status quo of the parties and turn the Communist Party into a machine rather than a revolutionary movement'. Seventh, Gough's data on the villages showed a moderately strong and highly significant association between caste and party affiliation, with higher castes favouring the Congress (further, some Muslims in the villages were Communists rather than League supporters). In spite of the correlation between caste rank and party support, she had argued against this indicating competitive casteism since 'caste strength is still closely related to socio-economic class, and the Congress/Communist cleavage is at least partly based on class' (ibid.: 416). Eighth, her fieldwork was carried out in the 1960s against the background of the recently concluded war between China and India; nonetheless, she perceived that Chinese action (she uses the word 'invasion') was 'not a "live" issue among the less educated Communist supporters. China was far away, and the details unknown to most people' (ibid.: 417). When it was suggested to the people that the Leftists might be betraying the nation, they responded that 'accusation [such as this] was designed to confuse the real, local issues of land, wages and prices', and opined that the two countries should arbitrate their disputes in a friendly manner, just as people in villages do when settling disputes over cashew trees and boundaries in the hills. Ninth, while personal friendships and reciprocal interests were in existence in the villages, the followers of both parties demonstrated a belief in the struggle against 'the anti-party', and even strove to evict such people. The use of physical violence against members of the anti-party was most probable just before or after an election. Further, it is important to take cognizance of the following remarks (ibid.: 420):

Each party faction has a few expert fighters as henchmen...faction leader denies his own responsibility for such assaults, attributing the blame to lesser individuals, while accusing the other party's leaders of financing and engineering counter-assaults, and sometimes of bribing the police to take no action. My information suggests that the party leaders of both sides may occasionally hire henchmen to carry out assaults on party-enemies, but that most such assaults are made by ad hoc groups of faction supporters who feel that they are defending the pride and interests of themselves and their party.

Footnote 26 (continued)

weed appeared in the tank in the dry season, they [Nayar women] stayed away and blamed it on the deity's wrath against the Communists' (Gough, 1965a: 367). Further, 'It has been the communists in Kerala, above all, who have visited Harijan houses, fraternized in low-caste tea shops, and upheld irregular marriages between persons of high and low caste' (Gough, 1965b: 416). In her work during this period, she observes the onset of challenges from lower caste and Communist-influenced groups to Nayar-dominated temples or mosques sermonising for the Muslim League. 
Thus, in the 1960s, the social life of a village was dominated by party competition, and party conflict ramified through all institutions, representing a long-term struggle for power between propertied and propertyless classes. The intensity of the class struggle and the challenge of accommodating the competing claims of different sections of society within the electoral setup in Kerala were reflected in the political turmoil and falls of successive governments in the 1950s and 1960s, and splits between both Communist and Congress parties in 1964, whereby the less moderate groups in both gained electorally. In this situation of continued tensions, the confrontation between parties with moderate incrementalist and radical egalitarian agendas created a deep polarisation that could not be easily settled. Electoral success then meant turning the revolution into a project that perforce had to accommodate to regressive social structures while maintaining economic equity and sustainable living. This being, perhaps, the only way to sustain a particular kind of egalitarian revolutionary politics in the electoral democratic mould.

In addition to the robust motives of hope and fear, the (communist) 'party village' phenomenon in contemporary times can be understood macro-politically through a combination of various explanations that take into account a multidimensionality of social, political, economic and ideological factors in context. At the social level, the continuing tension in the villages between committed anti-parties could only be resolved by geographical segregation of party loyalties. Moreover, in the party villages, the membership of the party is not merely a political affiliation but a significant part of lived identity and provides meaningful experience in family and community domains. The ontological cohesion of the village 'self' is a security gain. Economically speaking, leftist politics does have to attend to subsistence and livelihood concerns, and allegiance to the party is sensible for welfarist reasons for the majority of those who lack material resources or those higher up in the caste hierarchy who will benefit from the clientelist networks provided by such a platform. As with any successful movement, the persistence of political power in these communist party villages demonstrates the established credentials of the party and its historical achievements, and the fervour of maintaining this hold attracts supporters to the continuation of the project. The innovations in decentralised planning and relatively more accountable government in the successive decades also mean that a well-established set of personal, kinship and community-infused clientelism serves the involved interests, until there is no proximate cause for alteration. In terms of institutions, the existence of opposition in the substantive sense in post-colonial democratic states is not a straightforward matter (see Daalder, 1966); the core political demands may come to be so vividly significant to the supporters of a party that while procedural democracy might be acceptable, active opposition might be seen as a distraction. In addition, the excessive amount of intra-party competition for prestige, resources and clients might simply crowd out inter-party competition. Further, successful political parties might be so strategically competent as to create forms of governmentality that bring together the perceived interests of a diverse group of people (who might arguably have opposed interests in structural terms), that the need for plural and diverse balancing of party politics between different social groups may not seem urgent. In ideological terms, it is true that 
electoral democracy imposes its own form upon the diffusion of revolutionary politics. In this sense, the Communist parties that take part in electoral democracy in the state have already accepted the constraints of electoral legitimation and the accommodations and evictions that it requires. After the initial terms of adjustment in the 1950s and 1960s, the Communists in Kerala adapted to these conditions at the village level. In a significant manner, the Communists adapting to the traditional Brahmanical hierarchies and Hindu religious temples and customs in these villages both partly 'defangs' them in the eyes of those who would otherwise support Congress and such, and also 'moderates' them in the eyes of those who would otherwise hold their atheism against them, and might switch to BJP/RSS and such. The spheres of culture and economy are together combined in this way to create a persistence of geographically specific areas of democratically consolidated political power for Communists, through a combination of appeal to egalitarian ideology and regressive structures.

In the coming years, the communist party village will ever more have to contend with the wider evolutions of nationalism in India (whereby Hindu nationalism is increasingly being used for state transformation), and more specifically, with the desperation of the BJP-RSS project to make greater inroads into Kerala at a party-political level. While the BJP repeatedly faces electoral failure in Kerala, the RSS has been rapidly expanding in Kerala. ${ }^{27}$ Electoral success in Kerala will be hard for the BJP, but we do not see it as impossible given how the recent years have witnessed a gradual expansion of the BJP in states that were hitherto almost impossible for them to govern; this was made possible by a combination of alliances, propaganda, weaponisation of preexisting resentments between different subgroups, manipulation of federalist structures and safeguards, legal/semi-legal/extra-legal means (and by the subversion of the very idea of legality in its own name, such as in Jammu and Kashmir). These states were previously well outside the BJP domain of influence, but the uses of the ritual Hinduism are not to be underestimated. The Communist party villages are clearly an eyesore for the RSS/BJP Hindutva India project, and their future is far from certain. The role played by technology in enabling newer senses of identity and belonging may be salient. In the 1960s, the villages reported that they were not concerned about the war with China because it was a distant issue for them. On our visit to the village in 2019, in the weeks prior to the elections in India, we found a diametrically opposed viewpoint on national security and the enemy Other. Kashmir and the anti-Pakistan hypermilitaristic rhetoric definitely found resonance with people. The country was seen as facing an imminent threat from this Other, and the BJP and Modi media rhetoric on Kashmir was persuasive for some of the people we met, even though the geopolitical issue was just as distant now as back then.

\footnotetext{
27 The increasing social success of RSS coupled with the political failure of BJP to win seats in Kerala has been noted in the media in the context of elections in the last few years (see Jishnu, 2016). It is beyond the scope of this present article to engage with this paradox, but it forms part of our ongoing work.
} 
Funding Kaul and Kannangara would like to thank the editor and reviewers of the journal, and acknowledge the support of the British Academy (UK-India) Seed Funding Grant for their collaborative project on Non-traditional Democratic Dynamics in the Field, 2018-2019, as part of which they also organised a workshop in Kerala on Political Loyalties in Post-Colonial Democracies in April 2019.

\section{Declarations}

Ethics Approval The raw primary data was originally obtained via participant observation as part of the second author's doctoral work at the University of Pondicherry, India (fieldwork during October 2014 to August 2016), and this work followed American Anthropological Association ethical guidelines.

Consent to Participate Informed consent was obtained from all individuals the researcher interacted with. The information used in the article, unless already in the public domain, has been anonymised.

Competing Interests The authors declare no competing interests. The authors have no affiliations with or involvement in any organisation or entity with any financial interest or noon-financial interest in the subject matter or materials discussed in this article. There are no conflicts of interest whatsoever.

Open Access This article is licensed under a Creative Commons Attribution 4.0 International License, which permits use, sharing, adaptation, distribution and reproduction in any medium or format, as long as you give appropriate credit to the original author(s) and the source, provide a link to the Creative Commons licence, and indicate if changes were made. The images or other third party material in this article are included in the article's Creative Commons licence, unless indicated otherwise in a credit line to the material. If material is not included in the article's Creative Commons licence and your intended use is not permitted by statutory regulation or exceeds the permitted use, you will need to obtain permission directly from the copyright holder. To view a copy of this licence, visit http://creativecommons.org/licenses/by/4.0/.

\section{References}

Alexander, K. C. (1968). Changing status of Pulaya Harijans of Kerala. Economic and Political Weekly, 3(26/28), 1071-1074.

Althusser, L. (2001) [1970]. Lenin and philosophy and other essays. Manhattan: New York University Press.

Anil, S. (2020). Twenty-four years on, has People's Plan brought a qualitative change in Kerala? The New Indian Express August 20. https://www.newindianexpress.com/states/kerala/2020/aug/20/twentyfour-years-on-has-peoples-plan-brought-a-qualitative-change-in-kerala-2186145.html

Berger, P., \& Luckmann, T. (1966). The social construction of reality: A treatise in the society of knowledge. Penguin Books.

Bhattacharyya, D. (2009). Of control and factions: The changing 'party-society' in rural West-Bengal. Economic and Political Weekly, 44(9), 59-69.

Bhattacharyya, D. (2010). Left in the lurch: The demise of the world's longest elected regime? Economic and Political Weekly, 45(3), 51-59.

Bourdieu, P. (1977). Outline of a theory of practice. Cambridge University Press.

Chaturvedi, R. (2015). Political violence, community and its limits in Kannur, Kerala. Contributions to Indian Sociology, 49(2), 162-187.

Chaturvedi, R. (2017). Understanding the majoritarian violence and politics of Kerala's Kannur. The Wire, March 7. https://thewire.in/politics/majoritarian-violence-politics-kerala-kannur

Chhibber, P. K., \& Petrocik, J. R. (1989). The puzzle of Indian Politics: Social cleavages and the Indian party system. British Journal of Political Science, 19(2), 191-210.

Curran, J. A. Jr. (1950). The RSS: Militant Hinduism. Far Eastern Survey, May 17, 19(10), 93-98.

Daalder, H. (1966). Government and opposition in new states. Government and Opposition, 1(2), 205-226. 
Dale, S. F. (1980). Islamic Society on the South Asian Frontier: The Mappilas of Malabar, 1498-1922. Clarendon Press.

Das, R., \& Mahmood, Z. (2015). Contradictions, negotiations and reform: The story of left policy transition in West Bengal. Journal of South Asian Development, 10(2), 199-229.

Davey, H. T. (1972). Review of Kerala: Yenan of India: Rise of Communist Power, 1937-1969 by Victor M. Fic. The Journal of Developing Areas, 6(2), 253-255.

De Leon, C., Desai, M., \& Tuğal, C. (2009). Political Articulation: Parties and the Constitution of Cleavages in the United States, India, and Turkey. Sociological Theory, 27(3), 193-219.

Devasia, T. K. (2016). Kannur political killings: flourishing 'party villages' lead to all kinds of malpractices. Firstpost November 3. https://www.firstpost.com/india/kannur-political-killings-flourishingparty-villages-lead-to-all-kinds-of-malpractices-3086642.html

Enyedi, Z. (2008). The social and attitudinal basis of political parties: Cleavage politics revisited. European Review, 16(3), 287-304.

Fic, V. M. (1970). Kerala, Yenan of India: Rise of Communist Power, 1937-1969. Nachiketa Publications.

Fleishman, J. A. (1988). Attitude organisation in the general public: Evidence for a bidimensional structure. Social Forces, 67(1), 159-184.

George, K. M. (1958). Malayalam Drama. Indian Literature, 1(2), 102-112.

Gough, K. (1965a). Village politics in Kerala -I. The Economic Weekly, 17(8), 363-372.

Gough, K. (1965b). Village politics in Kerala -II. The Economic Weekly, 17(9), 413-420.

Gough, K. (1967). Kerala politics and the 1965 elections. International Journal of Comparative Sociology, 8(1), 55-88.

Gough, K., Aberle, D., Feddema, V., \& Chernenkoff, D. (1993). Kathleen Gough: a bibliography (Anthropology, Imperialism and Resistance: The Work of Kathleen Gough). Anthropologica, 35(2): 291-298.

Hardgrave, R. (1964). Caste in Kerala: A preface to the elections. Economic and Political Weekly, November 21. 1841-1847.

Harrison, S. (1960). India: The most dangerous decades. Princeton University Press.

Heath, O. (2005). Party systems, political cleavages and electoral volatility in India: A state-wise analysis 1998-1999. Electoral Studies, 24, 177-199.

Heller, P., \& Isaac, T. T. M. (2005). The politics and institutional design of participatory democracy: Lessons from Kerala, India. in Democratizing Democracy: Beyond the Liberal Democratic Canon, edited by Boaventura de Sousa Santos, 405-443. Verso.

Herzog, L., \& Zacka, B. (2019). Fieldwork in political theory: Five arguments for an ethnographic sensibility. British Journal of Political Science, 49(2), 763-784.

Ishiyama, J. T. (1999a). The Communist Successor Parties and Party Organizational Development in PostCommunist Politics. Political Research Quarterly, 52(1), 87-112.

Ishiyama, J. T. (1999b). Sickles into roses: The successor parties and democratic consolidation in postCommunist politics. Democratization, 6(4), 52-73.

Janos, A. C. (1993). Continuity and change in Eastern Europe: Strategies of post-communist politics. East European Politics and Societies, 8(1), 1-31.

Jishnu, L. (2016). BJP won't capture Kerala yet but RSS culture is sweeping the state. The Wire May 18. https://thewire.in/communalism/bjp-wont-capture-kerala-yet-but-rss-culture-is-sweeping-the-state

Kannangara, N., \& Devarapalli, J. (2019). Democracy and the politics of dress, colour, and symbols: An anthropological study of Kerala Politics. The Oriental Anthropologist, 19(1), 1-16.

Kannangara, N. (2018). Democracy, politics and violence in Kerala: An ethnographic study. PhD dissertation, Pondicherry University.

Kaul, N. (2017). Rise of the Political Right in India: Hindutva-development mix, Modi Myth, and dualities. Journal of Labor and Society, 20(4), 523-548.

Kavitha, K. (2019). Power politics in the myth and poetry of Theyyam. Adalaya Journal, 8(9). https:// adalyajournal.com/VOLUME-8-ISSUE-9-SEPTEMBER-2019/gallery/67-sep-1786.pdf/

Kerala Bureau. (2018). Nokkukooli: the ban and the after. The Hindu May 19. https://www.thehindu.com/ news/national/kerala/the-ban-and-after/article23938226.ece

Kerswell, T. (2018). Studies of the Indian Communist Movement. Journal of Labor and Society, 21, 415-430.

Kurien, P. (1994). Colonialism and ethnogenesis: A study of Kerala, India. Theory and Society, 23(3), $385-417$.

Kurup, P. R. (1985). Ente Nadinte Katha Enteyum, Trivandrum: National Book Stall. 
Lieten, G. K. (1975). Commnnism [sic] and communalism in Kerala. Review of Kerala: Politico-Social Structure and Development of an Indian State by Manfred Turlach. Economic and Political Weekly, 10(3), 71-74.

Lieten, G. K. (1977). Education, ideology and politics in Kerala 1957-59. Social Scientist, 6(2), 3-21.

Lieten, G. K. (1979a). Caste in class politics. Economic and Political Weekly, 14(7/8), 313-328.

Lieten, G. K. (1979b). Progressive state governments: An assessment of First Communist Ministry in Kerala. Economic and Political Weekly, 14(1), 29-39.

Lipset, S. M., \& Rokkan, S. (1967). Party Systems and Voter Alignments: Cross-National Perspectives. Free Press.

Lobo, S. (2017). The demarcated political zones of Kerala. India Today, August 6. https://www.indiatoday.in/ india/story/demarcated-political-zones-kerala-cpi-rss-bjp-1028217-2017-08-06

Mannathukkaren, N. (2013). The rise of the national popular and its limits: Communism and the cultural in Kerala. Inter-Asia Cultural Studies, 14(4), 494-518.

Mannathukkaren, N. (2016). Communalism sans violence: A Keralan exceptionalism. Sikh Formations, 12(23), 223-242.

Mark, D., \& Verien, J. M. (2008). The social construction of communities: Agency, structure and identity in the pre-Hispanic South West. Rowman \& Littlefield Publishers.

Mencher, J. P. (1980). Lessons and non-lessons of Kerala: Agricultural labourers and poverty. Economic and Political Weekly, 15(41/43), 1781-1802.

Mencher, J. P. (1993). Kathleen Gough and research in Kerala (Anthropology, Imperialism and Resistance: The Work of Kathleen Gough). Anthropologica, 35(2), 195-201.

Menon, D. (1994). Caste, nationalism and communism in South India: Malabar, 1900-1948. Cambridge University Press.

Menon, D. (1999). Being a Brahmin the Marxist way: E. M. S. Nambudiripad and the pasts of Kerala. In Invoking the Past: The Uses of History in South Asia, edited by Daud Ali, 40-66. Oxford University Press.

Menon, R., \& Sudhakaran, P. (2016). Where villagers wear the party colour. The Times of India. May 16. https://timesofindia.indiatimes.com/elections-2016/kerala-elections-2016/Where-villagers-wear-theparty-colour/articleshow/52286545.cms

Miller, R. E. (1976). Mappila Muslims of Kerala: A Study in Islamic Trends. Orient Longman.

Moyarath, J. (2012). Moyarath Shankaran: Athmakadhayum Charithra Smaranakalum. Chintha Publishers.

Nair, B. A. (1994). The dynamics of Kerala politics. The Indian Journal of Political Science, 55(3), 251-260.

Nossiter, T. J. (1982). Communism in Kerala: A study in political adaptation. University of California Press.

Panikkar, K. N. (1989). Against lord and state: Religion and peasant uprising in Malabar, 1836-1921. Oxford University Press.

Pulickaparampil, M. (1963). Some social determinants of political preference in Kerala State, India. Master's Thesis. Paper 1804. http://ecommons.luc.edu/luc_theses/1804

Ratcliffe, J. (1978). Social justice and the demographic transition: Lessons from India's Kerala state. International Journal of Health Services, 8(1), 123-144.

Rohrschneider, R., \& Whitefield, S. (2009). Understanding cleavages in party systems: Issue position and issue salience in 13 post-communist democracies. Comparative Political Studies, 42(2), 280-313.

Seethi, K. M. (2007). M.N. Vijayan: The scholar who knew too much. Mainstream XLV(45) October 27. https://www.mainstreamweekly.net/article386.html

Shahina, K. K. (2012). Dread and belonging in Kerala's party villages. Open Magazine, August 4 . https:// openthemagazine.com/features/india/dread-and-belonging-in-keralas-party-villages/

Sunilraj, B., \& Heath, O. (2017). The historical legacy of party system stability in Kerala. Studies in Indian Politics, 5(2), 193-204.

Törnquist, O. (2001). Movement, politics and development: The case of Kerala. The Social Scientist, 29(11/12), 57-87.

Turlach, M. (1970). Kerala: Politisch-soziale Struktur und Entwicklung eines indischen Bundeslandes [Kerala: Politico-Social Structure and Development of an Indian State]. Harrassowitz.

Oommen, J. (1992). Political instability in Kerala. The Indian Journal of Political Science, 53(4), 524-535.

Oommen, J. (1995). Politics of communalism in Kerala. Economic and Political Weekly, 30(11), 544-547.

Ullekh, N. P. (2018). Kannur: India's bloodiest revenge politics. Penguin Random House India.

Unithiri, N. V. P. (2005). Karivelloorinte Charithram. in Karivelloor Smaranika Kannur: CPI-M Karivelloor Area Committee.

Vanaik, A. (2007). The Paradoxes of Indian Politics. History Compass, 5(4), 1078-1090. 
Whitefield, S. (2002). Political cleavages and post-communist politics. Annual Review of Political Science, 5, 181-200.

Wood, C. (1987). The Moplah Rebellion and its genesis. People's Publication House.

Publisher's Note Springer Nature remains neutral with regard to jurisdictional claims in published maps and institutional affiliations.

\section{Authors and Affiliations}

\section{Nitasha Kaul ${ }^{1} \cdot$ Nisar Kannangara ${ }^{2}$}

$\triangle$ Nitasha Kaul

N.Kaul@westminster.ac.uk

Nisar Kannangara

nisar@nias.res.in

1 Politics and International Relations, Centre for the Study of Democracy, University of Westminster, Wells Street, London, UK

2 Inequality and Human Development Program, National Institute of Advanced Studies, Indian Institute of Science Campus, Bengaluru, India 